\title{
Combining multiple nutrient stresses and bicarbonate addition to promote lipid accumulation in the diatom RGd-1
}

\author{
Authors: Karen M. Moll, R.D. Gardner, E.O. \\ Eustance, Robin Gerlach, \& Brent M. Peyton
}

NOTICE: this is the author's version of a work that was accepted for publication in Algal Research. Changes resulting from the publishing process, such as peer review, editing, corrections, structural formatting, and other quality control mechanisms may not be reflected in this document. Changes may have been made to this work since it was submitted for publication. A definitive version was subsequently published in Algal Research, 5, July 2014, DO\#\#10.1016/ j.algal.2014.04.002.

Moll KM, Gardner RD, Eustance EO, Gerlach R, Peyton BM, "Combining multiple nutrient stresses and bicarbonate addition to promote lipid accumulation in the diatom RGd-1," Algal Research July 2014 5:7-15 


\title{
Combining multiple nutrient stresses and bicarbonate addition to promote lipid accumulation in the diatom RGd-1
}

\author{
K.M. Moll ${ }^{\text {a }}$, R.D. Gardner ${ }^{\text {b }}$, E.O. Eustance ${ }^{\text {c,d }}$, R. Gerlach ${ }^{\text {b }}$, B.M. Peyton ${ }^{b}, *$ \\ a Montana State University, Department of Microbiology and Center for Biofilm Engineering, Bozeman, MT 59717, United States

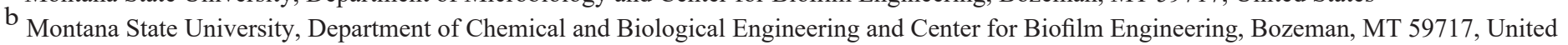 \\ States \\ c Arizona State University, School of Sustainable Engineering and the Built Environment, Tempe, AZ 85287, United States \\ d Arizona State University, Laboratory for Algal Research and Biotechnology, Arizona Center for Algal Technology and Innovation, Mesa, AZ \\ 85212, United States
}

Keywords:

A b s t r a c t

Diatoms

Silica

Lipids

Biodiesel

Algae

Algal biofuels represent a renewable, potentially viable, solution to mitigate transportation fuel demands. A novel diatom strain, RGd-1, isolated from Yellowstone National Park, produces high concentrations of lipids that can be converted to biodiesel. To increase the cell concentration and determine optimal conditions for growth, RGd-1 was grown without added Si, in the presence of four Si concentrations within the soluble range (0.5$2 \mathrm{mM}$ ), and one above the soluble range $(2.5 \mathrm{mM})$. Medium Si concentrations and intracellular triacylglycerol (TAG) con-tent were monitored daily by inductively coupled plasma mass spectrometry and Nile Red fluorescence, respec-tively (end-point TAG values were measured using gas chromatography). Si depletion with or without combined nitrate ( $\mathrm{NO}_{3}^{-}$) limitation was shown to induce TAG accumulation. Additionally, the effects of sodium bicarbonate $\left(\mathrm{NaHCO}_{3}\right)$ supplementation were examined on cultures grown using two $\mathrm{NO}_{\overline{3}} \overline{\text { concentrations }}(2.94 \mathrm{and} 1 \mathrm{mM} \mathrm{NO} \overline{3})$, which also resulted in increased TAG accumulation. It was determined that utilizing a combination of two independent physiological stresses and $\mathrm{HCO}_{3}$ supplementation resulted in the highest total and per cell TAG accumulation.

Introduction

Algal biofuels represent a potential alternative to petroleum-based transportation fuels. Capturing up to $2 \mathrm{~g}$ of atmospheric $\mathrm{CO}_{2}$ per gram of biomass, algae utilize a problematic greenhouse gas while producing biodiesel precursors [1,2]. The 2007 Energy Independence and Security Act and Renewable Fuel Standard (RFS) sought to increase the contribu-tion of renewable sources for energy production as well as decrease in greenhouse gas emissions. The RFS calls for production of 36 billion gal of renewable fuels by 2022 [3,4]. To meet this require-ment, fundamental research is still required to improve the algal biofuel viability. Specifically, research into improved strain selection and cul-turing strategies to enhance algal biodiesel potential (BP) ${ }^{1}$ have been identified as having the highest potential impact [5]. Paramount to algal biofuel feasibility is strain selection [6-8]. Some algal strains naturally contain high lipid concentrations in the form of triacylglycerol (TAG) [9,10]. Promising strains for use in biofuel produc-tion should have fast growth rates and high TAG content [3,8].Inmost cases, substantial TAG accumulation does not occur while cells are rapidly growing, rather, TAG accumulates when cells are stressed by factors such as nutrient depletion, $\mathrm{pH}$, temperature, light intensity or photoperiodicity [11-13]. When faced with nutrient limitations such as Si,2 diatoms appear to direct carbon storage towards TAG, which can be converted for use in biodiesel production [14].In addition to Si depletion, nitrogen stress and chemical addition are alternative methods to induce TAG accumulation in diatoms. For in-stance, Gardner et al. [10,15] combined nitrate depletion with sodium bicarbonate (NaHCO3) addition, to accelerate TAG accumulation in green algae (Scenedesmus sp. \& Chlamydomonas rheinhardtii) and the diatom, Phaeodactylum tricornutum during the late exponential growth phase just prior to NO3- depletion. The results demonstrated that HCO3 - addition can induce TAG accumulation across diverse taxa including freshwater and marine strains of green algae and diatoms. Another

1 Triacylglycerol (TAG), monoacylglycerol (MAG), diacylglycerol (DAG), fatty acid methyl esters (FAME), dissolved inorganic carbon (DIC), Yellowstone National Park (YNP), Field Emission-Scanning Electron Microscopy (FE-SEM), inductively coupled plasma-mass spectrometry (ICPMS), ion chromatography (IC), photosynthetically active radiation (PAR), dry cell weight (DCW), ash free dry weight (AFDW), biofuel potential (BP), gas chromatography-mass spectrometry (GC-MS), gas chromatography-flame ionization detection (GC-FID), relative fluorescence units (rfu), internally transcribed spacer (ITS).

2 The dissolved forms of silica are monomeric and dimeric silicic acid ( $\mathrm{Si}(\mathrm{OH}) 4)$, which diatoms incorporate into their cell walls in the solid form of silica ( $\mathrm{SiO} 2)$. In an attempt to simplify this matter, the dissolved and solid forms of silicon will herein be referred to as Si and silica, respectively. 
study by White et al. [16] observed increased total lipid per cell when two marine species, Tetraselmis suecica and Nannochloropsis salina, were cultured in two different concentrations of $\mathrm{HCO}_{3}^{-}$from the onset of each experiment. While their data indicate increased lipid accumulation, their results did not display the dramatic rate of increase observed by Gardner et al. [10] when $\mathrm{HCO}_{3}^{-}$was added just prior to $\mathrm{NO}_{3}^{-}$ depletion.

Here we focus on a diatom strain, designated RGd-1, isolated from an alkaline stream in Yellowstone National Park, USA. Diatom cell numbers and TAG accumulation were increased through the control of Si and $\mathrm{NO}_{3}^{-}$concentrations as well as the addition of $\mathrm{HCO}_{3}^{-}$. To our knowledge this is the first investigation using two combined physiological stresses and $\mathrm{HCO}_{3}^{-}$addition to increase lipid accumulation in diatoms. The goals of this study were to (1) determine the optimal Si concentration for RGd-1 growth and lipid accumulation and (2) increase lipid content per cell by combining physiological stresses, including $\mathrm{Si} / \mathrm{NO}_{3}^{-}$limitation and the addition of $\mathrm{HCO}_{3}^{-}$for the diatom isolate RGd- 1 .

\section{Material and methods}

\subsection{Diatom isolation and molecular characterization}

RGd-1 (Fig. 1) was isolated from a sample collected from Witch Creek ( $\mathrm{pH}$ 9.3) in the Heart Lake area of Yellowstone National Park (USA) containing both stream water and sediment. Environmental samples were streaked for isolation and individual colonies were selected and inoculated into various growth media types. This procedure was performed three times to ensure strain isolation, after which the cultures were treated with ampicillin to inhibit bacterial growth. Following this procedure, there was no evidence of bacterial growth upon inoculation of Bold's Basal Medium supplemented with 0.05\% glucose and $0.05 \%$ yeast extract and incubated in the dark $[17,18]$. Additionally, RGd-1 was determined to be unialgal by clone library analysis using 25 clones each for both $18 \mathrm{~S}$ rDNA and internally transcribed spacer (ITS) region as well as microscopic observation (light, epifluorescent, field emission-scanning electron microscopy (FE-SEM) and confocal laser scanning microscopy).

Based on frustule morphology observed using FE-SEM, the initial identity was thought to be a Navicula-like diatom [19]. Based on cellular morphology, RGd-1 resembles a Navicula-like diatom [19]. While cellular morphology may be used as a preliminary guide for identification, molecular techniques are also required. Amplification of SSU rDNA (18S), revealed that RGd-1 had the closest sequence similarity (96\%) to Lemnicola hungarica with $99 \%$ sequence coverage [20,21]. Full length ITS amplification was additionally performed to obtain greater

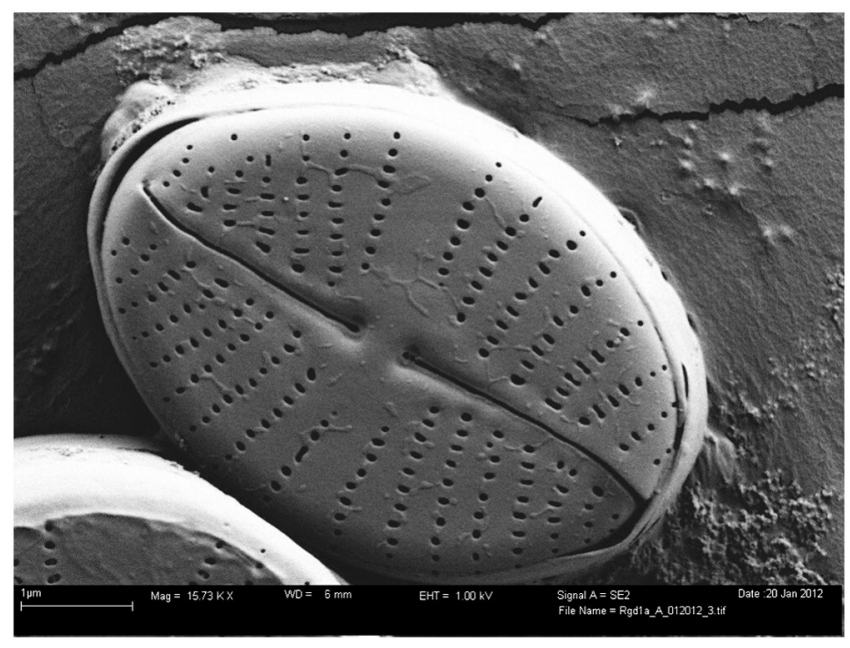

Fig. 1. Field emission-scanning electron microscopy (FE-SEM) image of RGd-1. resolution for strain identification, the results of which revealed $94 \%$ sequence similarity with its closest match, Sellaphora pupula. However, only $21 \%$ of the RGd- 1 ITS region aligned to its closest match. To further clarify RGd-1 identity, the ribulose-1,5-bisphosphate carboxylase/ oxygenase (RuBisCO) large subunit ( $\mathrm{rbcL}$ ) was amplified and found to share $93 \%$ sequence similarity with $100 \%$ sequence coverage to L. hungarica. Considering that RGd-1 SSU rDNA had closest sequence similarity no greater than $96 \%$, it likely belongs to a genus/species that has not been described thus far and further characterization is required.

DNA was extracted from $2 \mathrm{~mL}$ diatom samples by adding $200 \mu \mathrm{L}$ of extraction buffer ( $1 \mathrm{M} \mathrm{NaCl}, 70 \mathrm{mM}$ Tris, $30 \mathrm{mM}$ NaEDTA, pH 8.6). The contents were centrifuged at $14,500 \times g$ for $1 \mathrm{~min}$ and the supernatant discarded. Fresh extraction buffer $(500 \mu \mathrm{L})$, sterile glass beads $(1 \mathrm{~mm})$, $125 \mu \mathrm{L} 2 \%$ (w/v) CTAB (Tris-Cl, pH 8.0, 1.4 M sodium chloride, Teknova) extraction solution and $200 \mu \mathrm{L}$ chloroform were added, and cells were disrupted by using a bead beater (Fastprep) at setting 6.5 for $45 \mathrm{~s}$. Extracts were centrifuged at $12,000 \times g$ for 15 min to separate the organic and aqueous phases. The aqueous phase was removed and dispensed into a sterile $1.5 \mathrm{~mL}$ centrifuge tube. To the extracts, $40 \mu \mathrm{L}$ of $3 \mathrm{M}$ sodium acetate were added as well as $5 \mu \mathrm{L}$ of RNase (Promega) and $480 \mu \mathrm{L}$ isopropanol (Molecular Grade, Fisher). The extract was incubated at $20{ }^{\circ} \mathrm{C}$ overnight and centrifuged at $12,000 \times \mathrm{g}$ for $15 \mathrm{~min}$ at $4{ }^{\circ} \mathrm{C}$ to pellet DNA. The pellet was washed with $200 \mu \mathrm{L}$ of $80 \%$ ethanol and centrifuged again. Once the pellet was air dried in a biosafety cabinet, it was resuspended in $100 \mu \mathrm{L}$ of $10 \mathrm{mM}$ Tris- $\mathrm{HCl}$. Template DNA was amplified using the following $18 \mathrm{~S}$ primers UNI7F (5' ACCTGGTTGATCCTGCCAG 3') and $1534 \mathrm{R}\left(5^{\prime}\right.$ TGATCCTTCYGCAGGTTCAC $\left.3^{\prime}\right)$ [22,23] as well as ITS 1 (5' TCCGTAGGTGAACCTGCGG 3') and ITS 4 (5' TCCTCCGCTTATTGATAT GC $3^{\prime}$ ) [23-27]. Additionally, rbcL primers were used to obtain greater specificity using forward (5' GATGATGARAAYATTAACTC $3^{\prime}$ ) and reverse (5' ATTTGDCCACAGTGDATACCA 3') primers [28]. Per $50 \mu \mathrm{L}$ PCR reaction, $2.5 \mu \mathrm{L}$ of each primer was added (final concentration $1 \mu \mathrm{M}$ ), as well as $25 \mu \mathrm{L}$ of GoTAQ ${ }^{\circledR}$ Green Master Mix, $5 \mu \mathrm{L}$ sample and $15 \mu \mathrm{L}$ DNase/RNase free water. Samples were amplified by PCR with the following parameters: initial denaturation of $2 \mathrm{~min}$ at $94^{\circ} \mathrm{C}$, followed by 40 cycles of $30 \mathrm{~s}$ at $94{ }^{\circ} \mathrm{C}, 1 \mathrm{~min}$ at $52{ }^{\circ} \mathrm{C}, 1.15 \mathrm{~min}$ at $72{ }^{\circ} \mathrm{C}$, and final extension of $7 \mathrm{~min}$ at $72{ }^{\circ} \mathrm{C}$.

Amplicons were run on a $0.7 \%$ agarose gel to verify size. The remaining amplification product was cleaned using a QIAquick PCR Purification Kit (Qiagen) and cloned using the PGEM ${ }^{-T}-\mathrm{T}$ Vector System II (Promega). Clones were grown in LB + ampicillin $(100 \mu \mathrm{g} / \mathrm{mL})$ after which plasmids were extracted using the QIAprep Spin Miniprep Kit (Qiagen). Samples were submitted to Functional Biosciences (Madison, WI) for DNA sequencing, aligned using Jalview (version 2.8) [29], and the identity was determined using Megablast searches (NCBI).

\subsection{Growth conditions}

RGd-1 was grown in modified Bold's Basal Medium titrated to $\mathrm{pH} 8.7$ (before autoclaving) with added sodium metasilicate $\left(\mathrm{Na}_{2} \mathrm{SiO}_{3} \cdot 9 \mathrm{H}_{2} \mathrm{O}\right)$ (Sigma-Aldrich), S3 vitamin solution and Vitamin $\mathrm{B}_{12}$, according to the ASP II medium recipe [18]. Preliminary screening results showed that RGd-1 gave the highest cell numbers and lipid accumulation when grown unbuffered at an initial $\mathrm{pH}$ between $\mathrm{pH} 8$ and 9. Cultures were grown under 14:10 light/dark (L/D) cycle, aerated with ambient air resulting in the presence of 8-9 $\mathrm{mg} \mathrm{C} \mathrm{L} \mathrm{L}^{-1}$ dissolved inorganic carbon (DIC) in a temperature controlled water bath $\left(27 \pm 1{ }^{\circ} \mathrm{C}\right)$. Diatom cultures were grown in triplicate $1.25 \mathrm{~L}$ photobioreactors illuminated with $400 \mu$ mole photons $\mathrm{m}^{-2} \mathrm{~s}^{-1}$ using twelve T5 $4 \mathrm{ft}$ fluorescent lights. The light intensity was measured using a photosynthetically active radiation (PAR) meter (LI-COR). Samples were collected daily just prior to the end of each light cycle. To quantify growth, a minimum of 400 cells were counted from each sample using a hemacytometer (Reichert) [30]. Sample pH was measured using a standard benchtop $\mathrm{pH}$ meter (Accumet). Prior to analysis by inductively coupled 
plasma-mass spectrometry (ICP-MS), or ion chromatography (IC) analysis, samples were filtered using $0.22 \mu \mathrm{m}$ filters (Whatman).

To increase diatom cell numbers, Bold's Basal Medium was modified with the following Si concentrations: $0.0,0.5,1.0,1.5,2.0$ and $2.5 \mathrm{mM} \mathrm{Si}$; with the last concentration being just above the solubility limit [31,32]. To determine whether testing conditions were statistically different, results were analyzed using a two-tailed Student's t-test assuming two samples with equal variances ( $\mathrm{p}<0.05$ ).

To further increase the lipid content per cell and induce $\mathrm{NO}_{3}^{-}$limited conditions by the time cells reached stationary phase of growth, the $\mathrm{NO}_{3}^{-}$concentration was decreased from $2.94 \mathrm{mM}$ (standard Bold's Basal Medium) to $1 \mathrm{mM} \mathrm{NO}_{3}^{-}$. This modification created a dual stress ( $\mathrm{Si}$ and $\mathrm{NO}_{3}^{-}$) on RGd-1 cultures. Sodium bicarbonate $(25 \mathrm{mM}$ ) was added to parallel cultures containing $1 \mathrm{mM}$ or $2.94 \mathrm{mM} \mathrm{NO}_{3}^{-}$. Each of these experiments contained $2 \mathrm{mM} \mathrm{Si}$. At the completion of each experiment, cultures were centrifuged at $5000 \times g$ for $10 \mathrm{~min}$. The pelleted biomass was lyophilized (Labconco Lyophilizer) and later used for TAG and fatty acid methyl ester (FAME) analyses (described in Sections 2.6 and 2.7).

\subsection{Dry cell weight (DCW)}

Dry cell weight (DCW) was determined by filtering samples using GF/F Glass Microfiber Filters (Whatman). Samples were weighed after drying at $60{ }^{\circ} \mathrm{C}$ for approximately $24 \mathrm{~h}$ and re-weighed at $48 \mathrm{~h}$ to ensure all water had evaporated. Ash free dry weight (AFDW) was determined by heating DCW samples to $500{ }^{\circ} \mathrm{C}$ for $4 \mathrm{~h}[33,34]$. The difference between the DCW and remaining ash is the ash free dry weight, which was approximately $70 \%$ of the DCW. Samples were weighed immediately upon retrieval from the furnace to minimize air vapor condensation.

\subsection{Nitrate and chlorophyll concentration}

Nitrate concentrations were measured by ion chromatography using an AS22 Anion-Exchange Column (Dionex) with a $4.5 \mathrm{mM} \mathrm{NaHCO}_{3} /$ $1.4 \mathrm{mM} \mathrm{Na}_{2} \mathrm{CO}_{3}$ buffer as eluent at a $1.0 \mathrm{~mL}$ flow rate. Nitrate was detected using a CD20 conductivity detector, and results were analyzed on PeakNet 5.2 Chromatography Workstation software. Chlorophyll was measured by centrifuging $1 \mathrm{~mL}$ of culture at $5000 \times \mathrm{g}$ for $10 \mathrm{~min}$, decanting and re-suspending in methanol. Samples were intermittently vortexed, sonicated and incubated at $4{ }^{\circ} \mathrm{C}$ for $1 \mathrm{~h}$. Following incubation, samples were centrifuged again at $5000 \times \mathrm{g}(10 \mathrm{~min})$ and read at 632 , 652 and $665 \mathrm{~nm}$ (Genesys 10-S, Thermo Electron Corporation). Total chlorophyll concentrations were calculated by adding chlorophylls a and c according the methods outlined by Ritchie [35].

\subsection{Silicon quantification}

Total elemental silicon was quantified by ICP-MS (Agilent Technologies $7500 \mathrm{ce}$ ). Isotopes of ${ }^{28} \mathrm{Si}$, ${ }^{29} \mathrm{Si}$, and ${ }^{30} \mathrm{Si}$ were measured simultaneously for each sample run on ICP-MS. Total silicon was quantified using ${ }^{28} \mathrm{Si}$ as it was the most abundant isotope with the greatest signal to noise ratio.

\subsection{TAG analysis}

The TAG content was estimated daily by staining cultures with Nile Red (9-diethylamino-5H-benzo $(\alpha)$ phenoxa-zine-5-one) (SigmaAldrich) ( $0.25 \mathrm{mg} / \mathrm{mL}$ suspended in acetone), adding $4 \mu \mathrm{g} / \mathrm{mL}$ sample [36] and quantified on a microplate reader (Bio-Tek) with 480/580 excitation/emission filters. An hour-long time course of Nile Red stained RGd-1 cultures revealed that a 4 min exposure to Nile Red resulted in maximum fluorescence. Cell cultures were diluted if cell concentrations were higher than $3 \times 10^{6}$ cells $\mathrm{mL}^{-1}$ to maintain Nile Red fluorescence linearity. Total Nile Red fluorescence was strongly correlated with TAG $\left(\mathrm{R}^{2}=0.987\right)$ which was in agreement with prior work [36-38]. Fold difference in Nile Red fluorescence (Fig. 8) was calculated by dividing the $15 \mathrm{~d}$ Nile Red fluorescence values by the 2 mM Si control. Error bars were calculated using the Delta Approximation Method [39].

Typically, algal biodiesel is derived primarily from TAGs. TAGs were extracted from dry diatom biomass (20 mg) in $5 \mathrm{~mL} 1: 1: 1$ chloroform/ hexane/tetrahydrofuran solution (triple solvent) and quantified using gas chromatography-flame ionization detection (GC-FID; Agilent $6890 \mathrm{~N}$ ) [15]. Samples were sonicated for a total of $2 \mathrm{~min}$ in the triple solvent, using four 30 second pulses in an ice bath. Extracts were centrifuged $(1380 \times \mathrm{g})$ for approximately $2 \mathrm{~min} .1 \mathrm{~mL}$ was removed and placed in a GC vial with $10 \mu \mathrm{L}$ octacosane ( $10 \mathrm{mg} \mathrm{mL}^{-1}$ in triple solvent) as an internal standard. Samples were analyzed using GC-FID with $1 \mu \mathrm{L}$ injections for quantification of free fatty acids, monoacylglycerols (MAGs), diacylgylcerols (DAGs) and TAGs using calibration standards (Mono-, Di-, and Triglycerides Kit; Sigma) on a 15 m RTX biodiesel column (Restek) according to Gardner et al. [15].

\subsection{FAME analysis}

FAMEs were extracted and quantified by direct in-situ transesterification [40] and GC-MS, respectively for quantification of the fatty acid profile, the degree of saturation, and total biodiesel potential from direct transesterification based on methods outlined by Bigelow et al. [41]. To perform transesterification, dry biomass (10 $\mathrm{mg}$ ) was added to $1 \mathrm{~mL}$ toluene and $2 \mathrm{~mL} 0.5 \mathrm{M}$ sodium methoxide (pure, titrated in methanol, Acros Organics). Samples were placed in $5 \mathrm{~mL}$ crimp cap serum vials and heated to $80^{\circ} \mathrm{C}$ for $30 \mathrm{~min}$ with intermittent vortexing. After cooling, $2 \mathrm{~mL}$ of $14 \%$ BF3-methanol (Thermo-Scientific) were added and the vials were re-heated as described above. Once samples had cooled, $0.8 \mathrm{~mL}$ saturated $\mathrm{NaCl}$ and $1.0 \mathrm{~mL}$ hexane were added. Samples were centrifuged at $1380 \times \mathrm{g}$ for $2 \mathrm{~min}$, after which, $1 \mathrm{~mL}$ was removed and placed in a GC vial with $10 \mu \mathrm{L}$ octacosane as an internal standard. FAMEs were quantified using gas chromatography-mass spectrometry (GC-MS; Agilent 6890 and 5973 Network MS). Dilutions $(1: 10)$ were performed if peak areas were greater than the linear range of the calibration standards (NLEA FAME mix; Restek, Bellefonte, PA), as occurred for C-16 and C-18 FAMEs. All other fatty acids were quantified by integrating peak areas of undiluted samples.

\section{Results}

\subsection{Si concentration}

As part of a Yellowstone National Park algal isolate screening, diatom strain RGd-1 was found to naturally contain high concentrations of TAGs (evident by Nile Red fluorescence); however, the final cell concentrations were lower than desired. To improve upon these results, the growth medium (modified Bold's Basal Medium described above) was supplemented with six different Si concentrations: 0, 0.5, 1.0, 1.5, 2.0 and $2.5 \mathrm{mM}$ Si. At the time of harvest, DCW (Table 1 ) was strongly correlated with the (starting) Si concentration $\left(R^{2}=0.965\right)$. Growth medium without added $\mathrm{Si}$ supported approximately four cell doublings

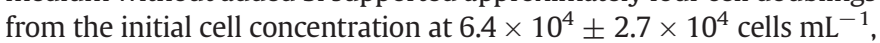
reaching a final cell concentration of $1.1 \times 10^{6} \pm 2.7 \times 10^{5}$ cells mL $^{-1}$ (mean \pm standard deviation) as indicated in Fig. 2 A. Potential sources of Si to support diatom cell replication can be attributed to intracellular Si storage, potential carryover from the RGd-1 inoculum or leaching from the borosilicate glass (Fig. S.1). When grown in $2.5 \mathrm{mM} \mathrm{Si}$, cell numbers reached $1.1 \times 10^{7} \pm 1.3 \times 10^{6}$ cells $\mathrm{mL}^{-1}$. Across each of the growth conditions, the cellular morphology and doubling time remained consistent at $29.4 \pm 1.4 \mathrm{~h}$ (Table 1 ). Therefore, cultures containing higher Si concentrations exhibited an apparent increase in cell numbers (Fig. 2 B).

Initially, and contrary to expectations, the higher Si concentrations (2-2.5 $\mathrm{mM})$ appeared to increase until it reached a maximum at seven days of growth (Fig. 2 B). For the $1.5-2.5 \mathrm{mM}$ initial Si conditions, 
Table 1

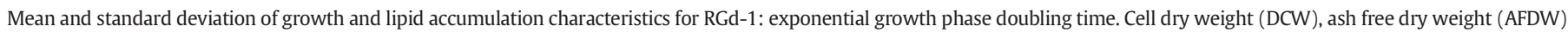

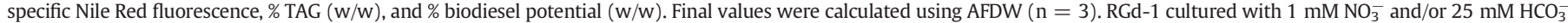
were each grown with $2 \mathrm{mM} \mathrm{Si}$.

\begin{tabular}{|c|c|c|c|c|c|c|}
\hline Condition & $\begin{array}{l}\text { Average doubling time } \\
\text { (h) }\end{array}$ & $\begin{array}{l}\mathrm{DCW} \\
(\mathrm{g} / \mathrm{L})\end{array}$ & $\begin{array}{l}\text { AFDW } \\
(\mathrm{g} / \mathrm{L})\end{array}$ & $\begin{array}{l}\text { Specific NR fluorescence } \\
\left(10,000 \mathrm{rfu}_{\text {cell }}^{-1}\right)\end{array}$ & $\begin{array}{l}\% \mathrm{TAG} \\
(\mathrm{w} / \mathrm{w})\end{array}$ & $\begin{array}{l}\% \mathrm{BP} \\
(\mathrm{w} / \mathrm{w})\end{array}$ \\
\hline $0 \mathrm{mM} \mathrm{Si}$ & $25.31 \pm 4.41$ & $0.05 \pm 0.01$ & $0.04 \pm 0.01$ & $23 \pm 3$ & $11.04 \pm 4.49$ & $40.17 \pm 18.21$ \\
\hline $0.5 \mathrm{mM} \mathrm{Si}$ & $27.07 \pm 0.43$ & $0.18 \pm 0.01$ & $0.12 \pm 0.01$ & $21 \pm 4$ & $32.21 \pm 2.00$ & $77.99 \pm 6.20$ \\
\hline $1.0 \mathrm{mM} \mathrm{Si}$ & $27.30 \pm 0.15$ & $0.32 \pm 0.03$ & $0.21 \pm 0.01$ & $20 \pm 3$ & $32.17 \pm 4.80$ & $70.37 \pm 10.81$ \\
\hline $1.5 \mathrm{mM} \mathrm{Si}$ & $27.42 \pm 1.03$ & $0.38 \pm 0.04$ & $0.25 \pm 0.05$ & $21 \pm 1$ & $34.55 \pm 8.38$ & $75.10 \pm 3.20$ \\
\hline $2.0 \mathrm{mM} \mathrm{Si}$ & $28.28 \pm 0.70$ & $0.50 \pm 0.06$ & $0.35 \pm 0.05$ & $25 \pm 6$ & $35.99 \pm 1.63$ & $76.93 \pm 1.89$ \\
\hline $2.5 \mathrm{mM} \mathrm{Si}$ & $25.55 \pm 2.38$ & $0.52 \pm 0.07$ & $0.35 \pm 0.06$ & $29 \pm 4$ & $35.16 \pm 1.40$ & $74.41 \pm 1.33$ \\
\hline $2.94 \mathrm{mM} \mathrm{NO}_{3}^{-}+\mathrm{HCO}_{3}^{-\mathrm{ab}}$ & $35.87 \pm 5.1$ & $0.62 \pm 0.01$ & $0.44 \pm 0.01$ & $34 \pm 2$ & $36.66 \pm 1.67$ & $80.68 \pm 2.59$ \\
\hline $1 \mathrm{mM} \mathrm{NO}_{3}^{-\mathrm{a}}$ & $29.89 \pm 2.9$ & $0.46 \pm 0.05$ & $0.30 \pm 0.04$ & $29 \pm 6$ & $38.24 \pm 5.58$ & $74.88 \pm 7.24$ \\
\hline $1 \mathrm{mM} \mathrm{NO}_{3}^{-}+\mathrm{HCO}_{3}^{-\mathrm{ab}}$ & $31.35 \pm 3.4$ & $0.52 \pm 0.01$ & $0.36 \pm 0.01$ & $43 \pm 6$ & $40.52 \pm 2.47$ & $76.12 \pm 4.54$ \\
\hline
\end{tabular}

a Cultured with $2.0 \mathrm{mM} \mathrm{Si}$.

b $25 \mathrm{mM} \mathrm{HCO}_{3}^{-}$.

early concentration measurements appeared lower than expected. This may be due to silica polymer formation promoted by $\mathrm{pH}$ or autoclaving. Between pH 10.9-13.6, disilicate ions are the predominant silicate species, however, below $\mathrm{pH} 10.9$, the disilicates polymerize into polysilicates or colloidal silica, that might have been removed during filtration prior to ICP-MS analysis [31]. Over time the polymers may have dissociated thus appearing as though the medium Si concentration increased.

Total chlorophyll (chlorophyll a $+\mathrm{c}$ ) was measured daily to monitor diatom cell health (Fig. 3 A). Chlorophyll concentrations increased with (initial) Si concentrations up to $1.5 \mathrm{mM}$ and then stabilized. As expected, there was an inverse relationship between the measured chlorophyll and nitrate concentrations with total $\mathrm{NO}_{3}^{-}$uptake increasing with cell numbers. Whereas cultures grown without added Si utilized
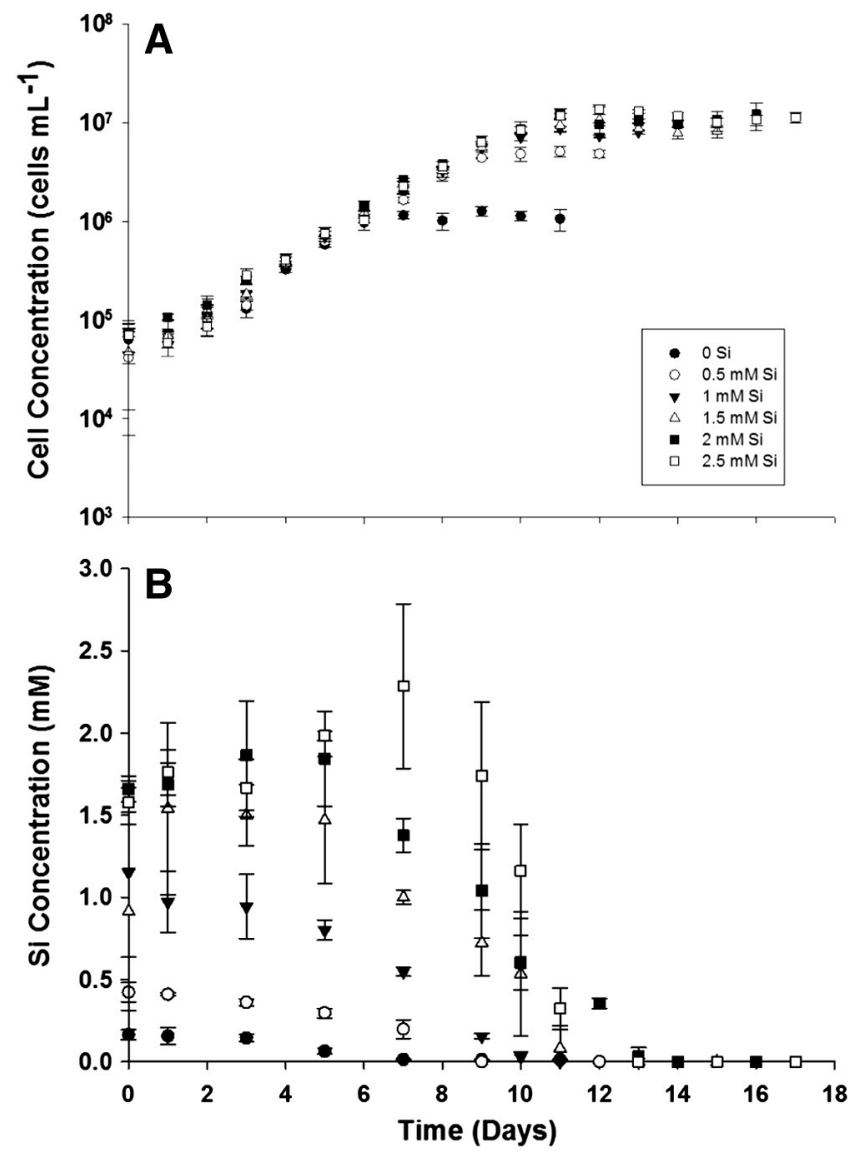

Fig. 2. Mean and standard deviation of (A) RGd-1 growth (cells $\mathrm{mL}^{-1}$ ) for six silica concentrations (0-2.5 mM) and (B) Silica concentration in the growth medium over time $(\mathrm{n}=3)$. less than $1 \%$ of the $\mathrm{NO}_{3}^{-}$in the growth medium, cells grown in $2.5 \mathrm{mM}$ Si utilized approximately $87 \%$ (Fig. 3 B). It should be noted that none of the cultures grown with $2.94 \mathrm{mM} \mathrm{NO}_{3}^{-}$reached a $\mathrm{NO}_{3}^{-}$limited lipid accumulation phase.

As shown in Fig. 4, cultures grown in higher Si concentrations reached higher maximum $\mathrm{pH}$ values and Nile Red fluorescence. When grown without added $\mathrm{Si}(0 \mathrm{mM} \mathrm{Si})$, the medium $\mathrm{pH}$ remained constant throughout growth at approximately $\mathrm{pH}$ 7.8. Cultures grown with higher Si concentrations reached greater maximum $\mathrm{pH}$ values, which remained elevated for extended periods of time. This effect is likely due to increased photosynthetic activity resulting in higher utilization of $\mathrm{H}_{2} \mathrm{CO}_{3}$ or $\mathrm{HCO}_{3}^{-}$from the growth medium, thus increasing the $\mathrm{pH}$ (Fig. $4 \mathrm{~A}$ ). Once the $\mathrm{pH}$ exceeded approximately 8.5, Nile Red fluorescence

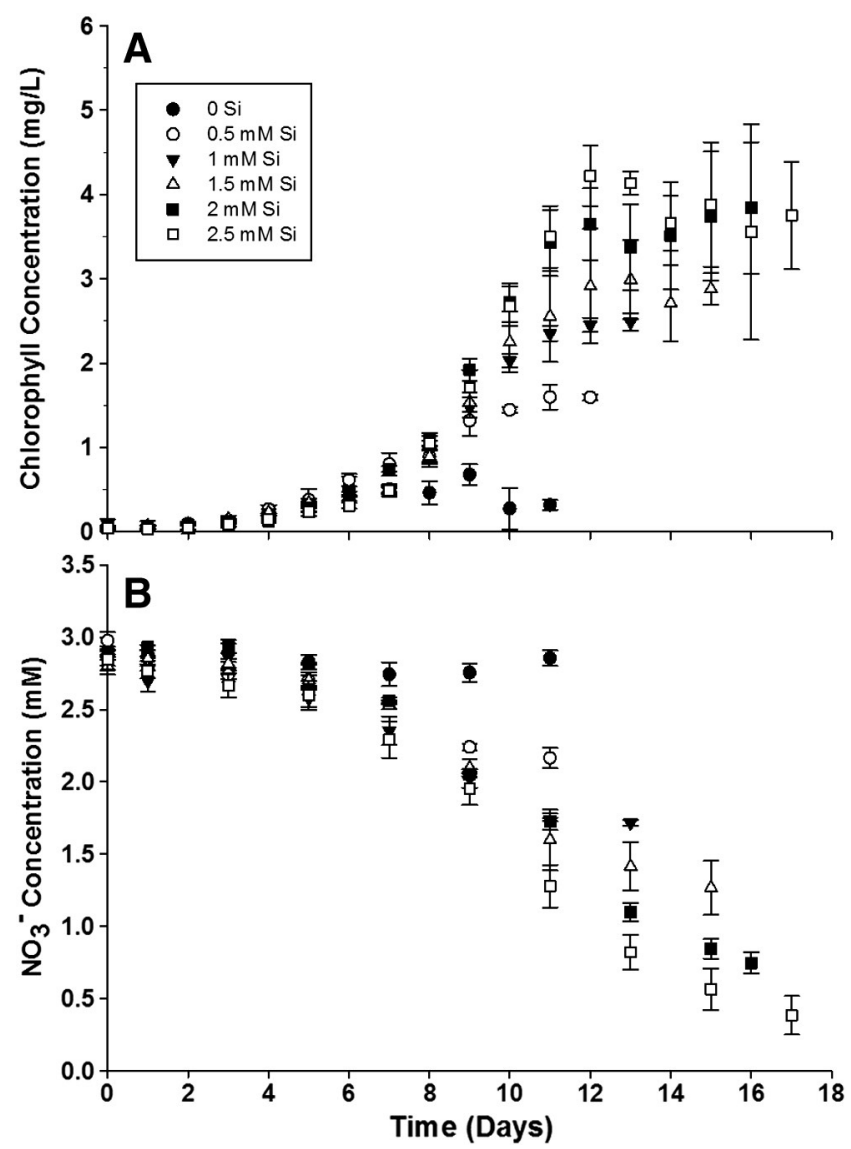

Fig. 3. Mean and standard deviation of (A) chlorophyll production and (B) $\mathrm{NO}_{3}^{-}$removal from growth medium for RGd-1 grown in each silica concentration $(n=3)$. 


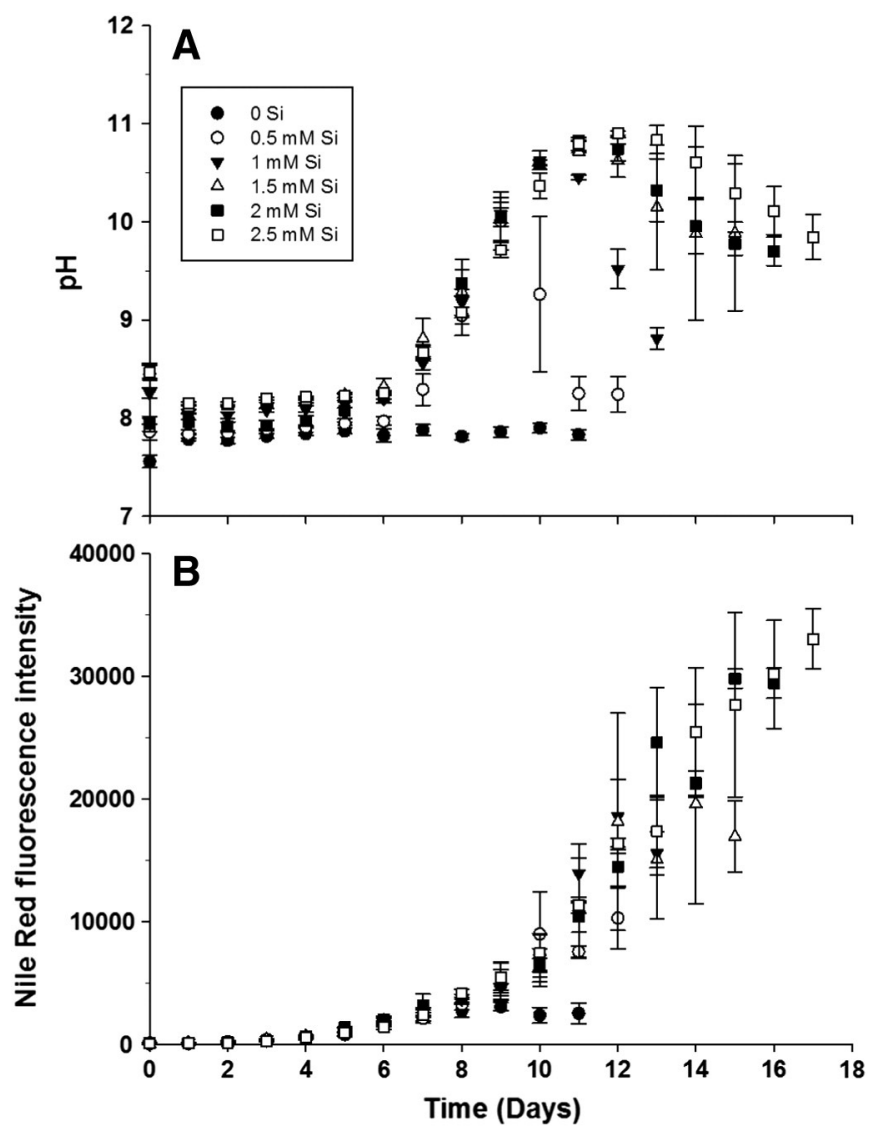

Fig. 4. Mean and standard deviation of (A) medium $\mathrm{pH}$ and (B) Nile Red fluorescence for RGd-1 grown in each silica concentration $(n=3)$.

exhibited a nominal increase. However, once Si was depleted from the growth medium, total and specific Nile Red fluorescence increased drastically with the highest values associated with the 2 and $2.5 \mathrm{mM}$ Si treatments. At the time of harvest, cultures grown with $2.5 \mathrm{mM}$ Si reached $33,030 \pm 2440$ relative fluorescence units (rfu) which was more than ten times the final Nile Red fluorescence of $2522 \pm 848 \mathrm{rfu}$ for cultures grown without Si addition (Fig. 4 B). Of the Si concentrations tested, the specific Nile Red fluorescence per cell was the highest at $25 \pm 6$ and $29 \pm 4$ rfu for 2 and $2.5 \mathrm{mM}$ Si treatments, respectively (Table 1 ).

RGd-1 grown in $2 \mathrm{mM}$ and $2.5 \mathrm{mM}$ Si yielded statistically the same cell concentrations, growth rates, AFDW, chlorophyll and Nile Red fluorescence. As verified using a two-tailed student t-test $(\mathrm{p}=0.963$, $\mathrm{t}$ critical $=2.120$ ), there was no significant difference between 2.0 and $2.5 \mathrm{mM} \mathrm{Si}$. Based on these results, $2 \mathrm{mM} \mathrm{Si}$ was chosen as the model Si concentration for further lipid accumulation studies under $\mathrm{NO}_{3}^{-}$limitation and $\mathrm{HCO}_{3}^{-}$addition.

\subsection{Bicarbonate addition and nitrate limitation}

The results in the studies described above indicate that increasing the $\mathrm{Si}$ concentration resulted in increased cell concentration and TAG accumulation. Building on the findings by Gardner et al., [9,10, 42], we hypothesized that lipid accumulation could be further improved using two simultaneous nutrient limitations and the addition of $\mathrm{HCO}_{3}^{-}$ [10]. As shown in Fig. 3 B, RGd-1 never depleted the $\mathrm{NO}_{3}^{-}$from standard Bold's Basal Medium. Therefore, to create coincident $\mathrm{Si}$ and $\mathrm{NO}_{3}^{-}$limitation stresses, cultures were grown in $2 \mathrm{mM} \mathrm{Si}$, and $\mathrm{NO}_{3}^{-}$concentrations were decreased to $1 \mathrm{mM}$. Additionally, $\mathrm{HCO}_{3}^{-}$was added to parallel cultures just prior to $\mathrm{Si}$ and/or $\mathrm{NO}_{3}^{-}$depletion. For these experiments, cultures were grown in Bold's Basal medium at standard $\mathrm{NO}_{3}^{-}(2.94 \mathrm{mM})$ or limited $\mathrm{NO}_{3}^{-}$concentration $(1 \mathrm{mM})$, with or without $\mathrm{HCO}_{3}^{-}$addition
(25 mM final concentration). Fig. 5 A shows the cell concentrations remained consistent across the four growth conditions tested with final cell concentrations ranging from $1.2 \times 10^{7} \pm 3.7 \times 10^{6}$ cells $\mathrm{mL}^{-1}$ (2.94 $\mathrm{mM} \mathrm{NO}_{3}^{-}$without $\mathrm{HCO}_{3}^{-}$) to $1.5 \times 10^{7} \pm 1.2 \times 10^{6}$ cells $\mathrm{mL}^{-1}$ (2.94 $\mathrm{mM} \mathrm{NO}_{3}^{-}$with $\mathrm{HCO}_{3}^{-}$) (Table 1, Fig. $5 \mathrm{~A}$ ). Si was depleted by approximately $12 \mathrm{~d}$ for each of the four growth systems (Fig. $5 \mathrm{~B}$ ). As expected, cultures grown with $1 \mathrm{mM} \mathrm{NO}_{3}^{-}$depleted the medium of $\mathrm{NO}_{3}^{-}$by approximately $10 \mathrm{~d}$ and cultures grown in standard $\mathrm{NO}_{3}^{-}$concentration (2.94 $\mathrm{mM} \mathrm{NO}_{3}^{-}$) remained replete with $\mathrm{NO}_{3}^{-}$(Fig. $5 \mathrm{C}$ ). After $12 \mathrm{~d}$, cultures grown with $1 \mathrm{mM} \mathrm{NO}_{3}^{-}$were found to contain less total chlorophyll than cultures grown with $2.94 \mathrm{mM} \mathrm{NO}_{3}^{-}$(Fig. 5 D). For the $1 \mathrm{mM} \mathrm{NO}_{3}^{-}$studies, once $\mathrm{NO}_{3}^{-}$was depleted, chlorophyll began to decrease by $11 \mathrm{~d}$, but was stable when grown in $2.94 \mathrm{mM} \mathrm{NO}-$ While chlorophyll degradation suggests diminished photosynthetic ability and consequent capacity to fix inorganic carbon, the results indicate that total and specific lipid accumulations were not adversely affected.

Cultures exposed to combined $\mathrm{Si}$ and $\mathrm{NO}_{3}^{-}$limitation stresses and $\mathrm{HCO}_{3}^{-}$addition exhibited higher Nile Red fluorescence (Fig. $5 \mathrm{E}$ and Table 1). When grown under Si limitation alone, the total Nile Red fluorescence was 29,430 \pm 2440 rfu. Combining $\mathrm{Si}$ and $\mathrm{NO}_{3}^{-}$limitation resulted in a slight increase in Nile Red fluorescence to $36,683 \pm$ $9126 \mathrm{rfu}$. When Si depletion was combined with $\mathrm{HCO}_{3}^{-}$addition, there was a substantial increase in Nile Red fluorescence to 50,613 \pm $3134 \mathrm{rfu}$. However, the most dramatic response was observed through the combination of the two physiological stresses and $\mathrm{HCO}_{3}^{-}$addition resulting in a total Nile Red fluorescence of 57,122 $\pm 1870 \mathrm{rfu}$, or approximately twice the Nile Red fluorescence for cultures exposed to Si stress alone (Fig. 6).

Cultures exposed to additive stresses reached higher specific Nile Red fluorescence as well. When grown under one stress (Si depletion), the specific Nile Red fluorescence was $25 \pm 6$ (Table 1 ). With two stresses (e.g., $\mathrm{Si}$ and $\mathrm{NO}_{3}^{-}$depletion or $\mathrm{Si}$ depletion with $\mathrm{HCO}_{3}^{-}$addition), specific Nile Red fluorescence reached $29 \pm 6$ and $34 \pm 2$, respectively (Table 1). However, when the two nutrient stresses were combined with $\mathrm{HCO}_{3}^{-}$addition, the specific Nile Red fluorescence reached the highest values at $43 \pm 6 \mathrm{rfu}$, which is evident in cultures that were imaged by transmitted light and epifluorescence microscopy (Fig. 7). Additionally, cultures with added $\mathrm{HCO}_{3}^{-}$maintained a slightly higher $\mathrm{pH}$ when compared to controls (Fig. 5F). This trend was consistent at both $1.0 \mathrm{mM} \mathrm{NO}_{3}^{-}$and $2.94 \mathrm{mM} \mathrm{NO}_{3}^{-}$, indicating a possible $\mathrm{pH}$ stress, and dissolved inorganic carbon (DIC) increase, with greater potential for lipid accumulation. These results indicate that additive stresses have significant potential to increase both specific and total TAG production in diatom cultures.

\subsection{Lipid quantification}

With exception of cultures grown without added $\mathrm{Si}$, all of the conditions tested resulted in very high TAG and BP content per weight of biomass. Compared to cultures without added Si which reached $11 \%$ (w/w) TAG and 40.2\% (w/w) BP, all other conditions reached $>32 \%$ $(\mathrm{w} / \mathrm{w})$ TAG and $>70 \%(\mathrm{w} / \mathrm{w})$ BP (AFDW) (Table 1$)$. Fig. 8 shows the total TAG content $(\mathrm{w} / \mathrm{v})$ in each system as calculated by Eustance et al. [43]. It is evident that greater total TAG production was achieved when cultures were grown with higher Si concentrations especially when combined with limiting $\mathrm{NO}_{3}^{-}$and supplemented with $\mathrm{HCO}_{3}^{-}$. Fig. 9 summarizes the composition of the extracted lipids from RGd-1 produced from cultures grown with $2 \mathrm{mM} \mathrm{Si}$. Each of the conditions tested resulted in similar FAME profiles as shown in Fig. 8. Approximately $95 \%$ of the FAMEs were composed of C14:0, C16:0, C16:1, C18:0, C18:1-3 and C20:5. Specifically, C16:0 (35\%) and C16:1 (30\%) encompassed the highest percentage of FAMEs. Cultures grown without added $\mathrm{Si}(0 \mathrm{mM} \mathrm{Si})$ resulted in approximately one-half of the BP $(40 \%)$ as compared to cultures grown where Si was present $(\mathrm{BP}=70-80 \%)$ (Table 1). 

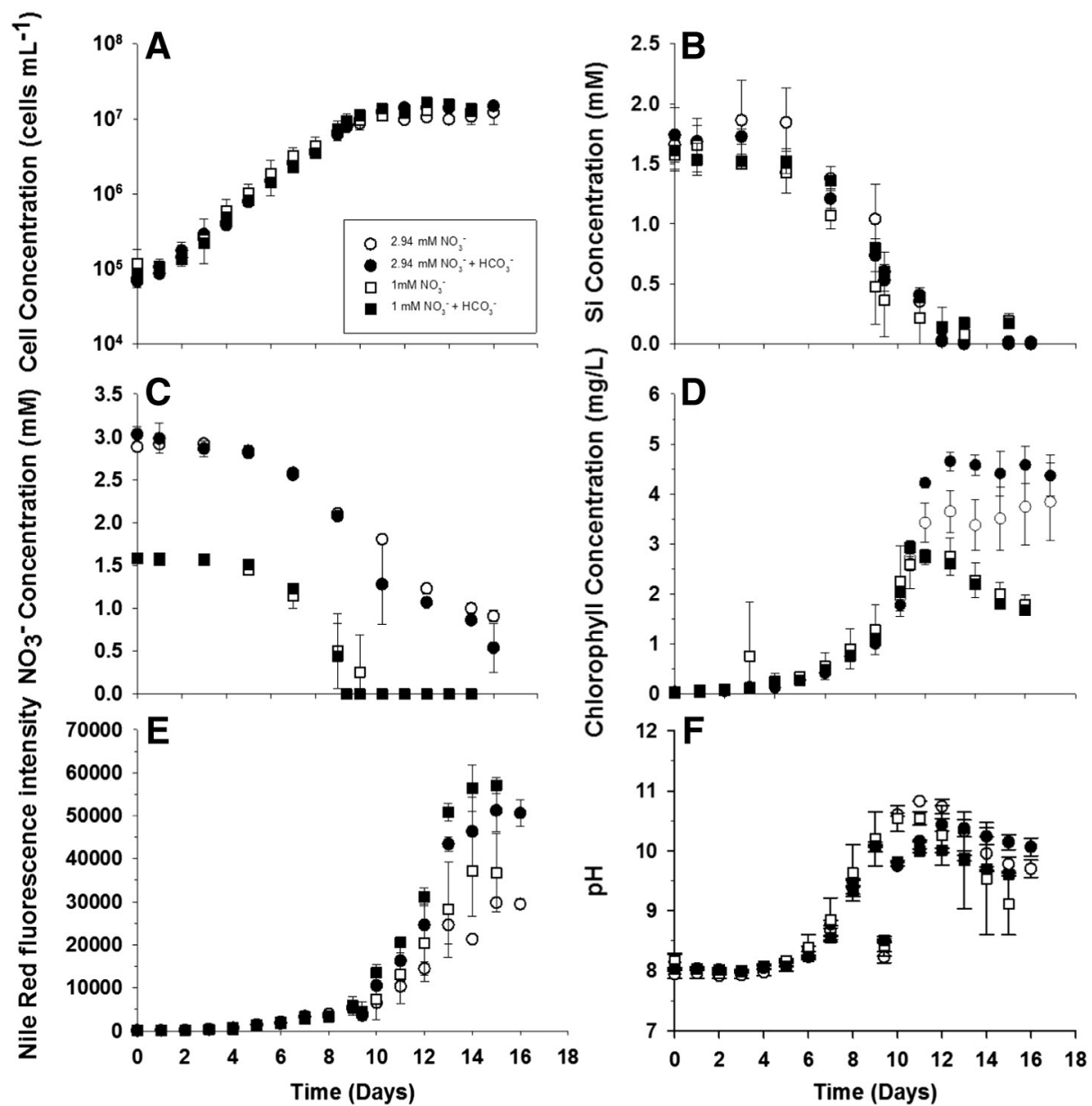

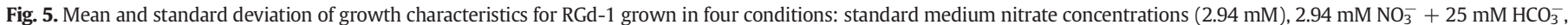

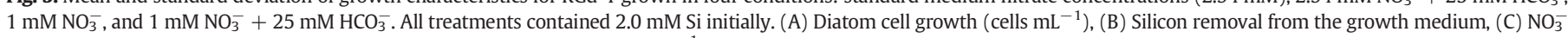
removal from the growth medium $(\mathrm{mM})$, (D) chlorophyll concentration $\left(\mathrm{mg} \mathrm{L}^{-1}\right)$, (E) Nile Red fluorescence intensity, and $(\mathrm{F}) \mathrm{medium} \mathrm{pH}(\mathrm{n}=3)$.

\section{Discussion}

\subsection{Effects of Si concentration}

Previous studies have explored the role of Si limitation on lipid accumulation for various diatoms. However, these studies were performed on marine diatoms [44] (e.g., Cylindrotheca spp. [14,45], Thalassiosira pseudonana, and P. tricornutum) [46] grown in media containing lower

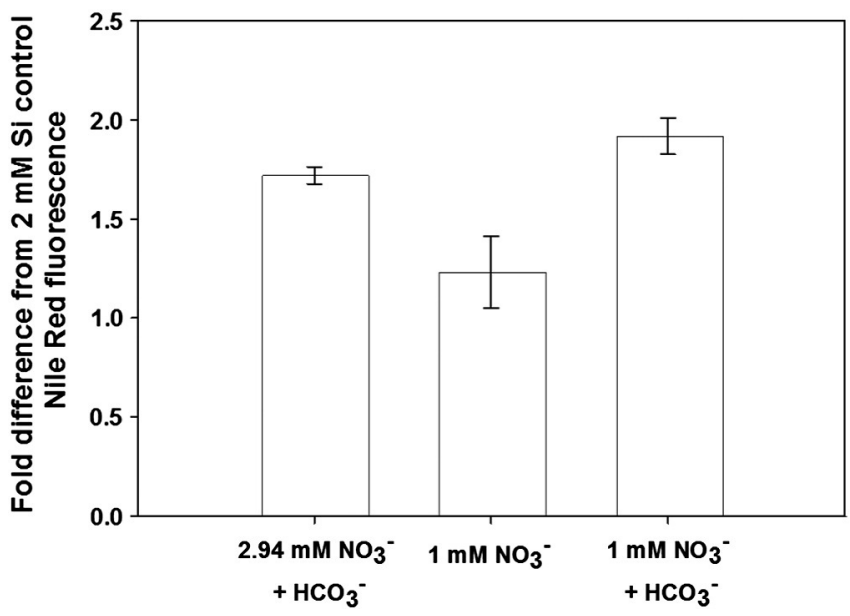

Fig. 6. Each bar represents the fold difference in Nile Red fluorescence intensities at $15 \mathrm{~d}$ for each treatment compared to the $2 \mathrm{mM}$ Si control.
Si concentrations than employed here (up to an order of magnitude less). While the use of marine strains may be advantageous in largescale outdoor raceway ponds to avoid using freshwater sources, the results presented here indicate that pursuing methods that increase the Si availability may lead to increased growth, which is important for improving algal biodiesel productivity.

Strains that thrive in extreme environments (e.g., high temperature, alkalinity or salinity) may have increased potential to be successful in outdoor raceway ponds $[2,47,48]$. Discovering novel strains with fast growth rates, high lipid contents and the ability to thrive in environments uninhabitable for competing (non-productive with respect to biofuel production) organisms is important for the industrial viability of algal biofuel production [2].

Based on doubling time, cell yield, DCW, TAG and biodiesel content, RGd-1 growth with $2 \mathrm{mM}$ Si was chosen as the optimum Si concentration for growth, which is approximately an order of magnitude greater than seawater. Diatoms utilize $\mathrm{Si}$ as silicic acid $\mathrm{Si}(\mathrm{OH})_{4}$ either in the monomeric or dimeric form. Both forms are in equilibrium with polymers eventually leading to dissipation of silica polymers as the diatom cell numbers increase [31]. Concentrations exceeding Si solubility ( $>2 \mathrm{mM}$ ) may result in polymerization, rendering Si potentially less biologically available [32]. When grown in the presence of 4 and $8 \mathrm{mM} \mathrm{Si}$, the doubling time increased to 33 and $37 \mathrm{~h}$, respectively (data not shown). It is hypothesized that this occurred as a result of diatoms utilizing monomeric and dimeric $\mathrm{Si}(\mathrm{OH})_{4}$ faster than it was liberated from the silicate polymers.

It is evident that higher initial Si concentrations ultimately lead to greater TAG accumulation. When grown in higher Si concentrations 

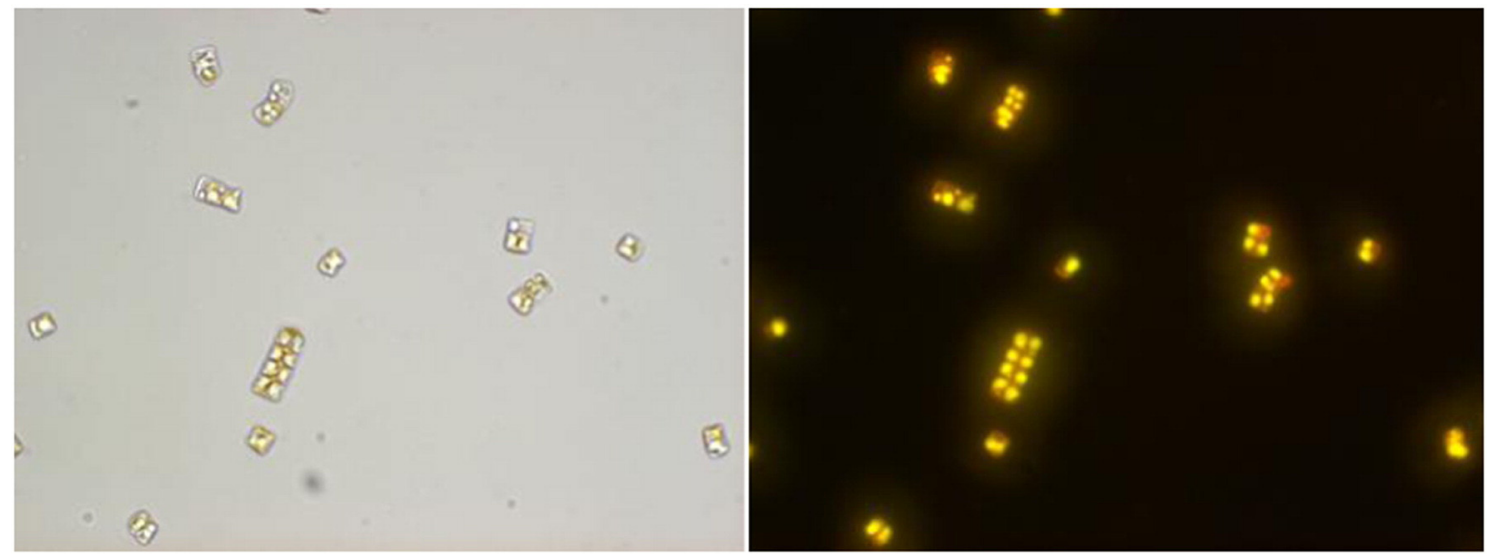

Fig. 7. Transmitted light (left) and epifluorescent microscopy images of RGd-1 stained with Nile Red (right).

(1.5-2.5 mM), cultures reached higher maximum medium $\mathrm{pH}$, which can be attributed to hydroxyl ion production as a result of the utilization of $\mathrm{HCO}_{3}^{-}$. Additionally, hydroxyl ions may be produced through the assimilation of $\mathrm{NO}_{3}^{-}[43,49]$ and $\mathrm{Si}(\mathrm{OH})_{4}$, respectively [31]. When grown in the presence of higher $\mathrm{Si}$ concentrations, the cell numbers increased, leading to greater $\mathrm{CO}_{2}$ and $\mathrm{NO}_{3}^{-}$utilization and concomitant $\mathrm{pH}$ increase. This effect was observed for all silica concentrations where higher silica concentrations resulted in higher culture $\mathrm{pH}$ values, which were maintained for longer periods of time. These cultures were less susceptible to $\mathrm{pH}$ decrease compared to the $0.5 \mathrm{mM}$ and 1 $\mathrm{mM}$ Si conditions in which the $\mathrm{pH}$ decreased significantly around 10 and $11 \mathrm{~d}$, compared to the $1.5-2.5 \mathrm{mM}$ Si conditions. Once the cells reached stationary phase of growth following Si depletion, they exhibited decreased photosynthetic ability, which was evident by lower $\mathrm{pH}$ (due to the accumulation of $\mathrm{H}_{2} \mathrm{CO}_{3}$ in the growth medium). Cultures grown with higher $\mathrm{Si}$ concentrations reached higher $\mathrm{pH}$ values due to greater $\mathrm{OH}^{-}$production associated with higher concentrations of $\mathrm{NO}_{3}^{-}$ and $\mathrm{Si}(\mathrm{OH})_{4}$, assimilation. The high $\mathrm{pH}$ reached at higher Si concentrations likely exposed the diatom to a pH stress as well, which has been shown to increase lipid accumulation in some microalgae $[9,10,13]$. Importantly, increased Si concentrations resulted in a greater number of cells with potential to produce more total TAG. While it may be

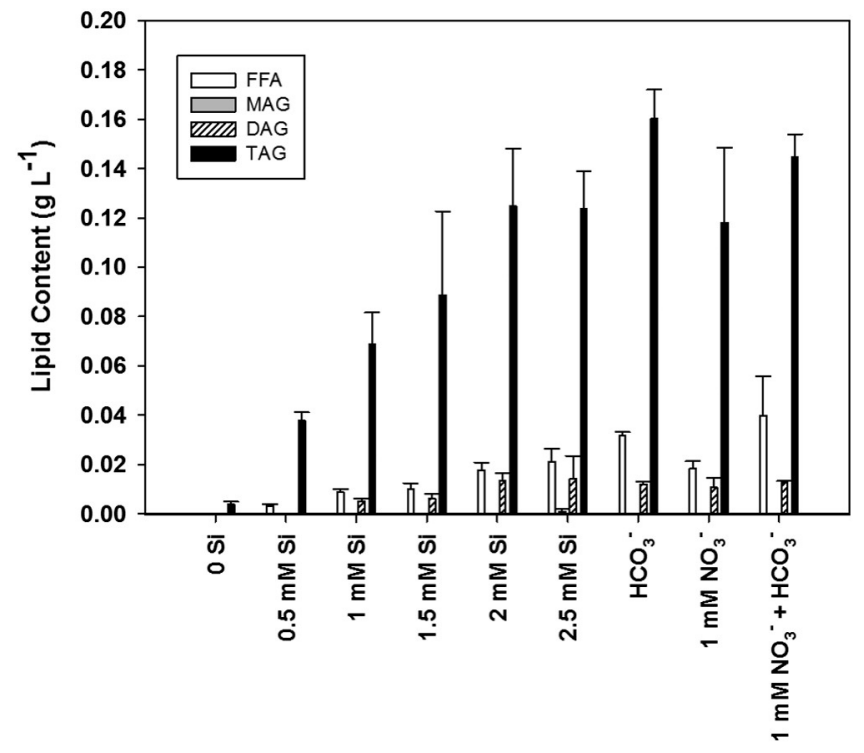

Fig. 8. Mean and standard deviation of MAG, DAG, and TAG of diatom AFDW ( $\mathrm{g} \mathrm{L}^{-1}$ ) of RGd-1 of grown in each condition tested $(n=3)$. RGd-1 cultured with $1 \mathrm{mM} \mathrm{NO}_{3}^{-}$ and/or $25 \mathrm{mM} \mathrm{HCO}_{3}^{-}$were each grown with $2 \mathrm{mM} \mathrm{Si}$. economically impractical to add $2 \mathrm{mM} \mathrm{Na}_{2} \mathrm{SiO}_{3} \cdot 9 \mathrm{H}_{2} \mathrm{O}$ on a large scale, the results presented here demonstrate the potential to improve cell and lipid concentrations when supplemented with high Si concentrations. Other Si sources are being evaluated and characterized to advance the results of this study to more commercially relevant conditions.

\subsection{Using additive stresses to increase TAG}

RGd-1 is capable of growth at high $\mathrm{pH}$, which is advantageous when $\mathrm{HCO}_{3}^{-}$can be utilized as a carbon source. Because RGd- 1 stores high concentrations of lipids, it is a promising candidate for biofuel production. Further, $\mathrm{RGd}-1$ was exposed to $\mathrm{Si}$ and $\mathrm{NO}_{3}^{-}$limitation along with $\mathrm{HCO}_{3}^{-}$addition and potentially a $\mathrm{pH}$ stress, which improved the accumulation of lipids $[9,10]$. The addition of $\mathrm{HCO}_{3}^{-}$served as both a buffer (pKa: 10.3) and a source of inorganic carbon for growth and/or TAG accumulation.

Nitrate limitation is known to decrease chlorophyll concentration, which has been shown to decrease photosynthetic rates in Chlamydomonas reinhardtii [50,51]. While $\mathrm{N}$ is a particularly important limiting nutrient in biofuel production for green algae [9,52-57], $\mathrm{N}$ limitation may increase lipid accumulation in diatoms as well [10,50,58,59]. Additionally, N depletion can limit protein synthesis required for desirable functions such as TAG accumulation [50]. However, the results of this study indicate that $\mathrm{NO}_{3}^{-}$limitation did not result in decreased lipid accumulation, rather there was a slight increase compared to cultures grown in $\mathrm{NO}_{3}^{-}$replete conditions. Previous studies by Olsen et al.

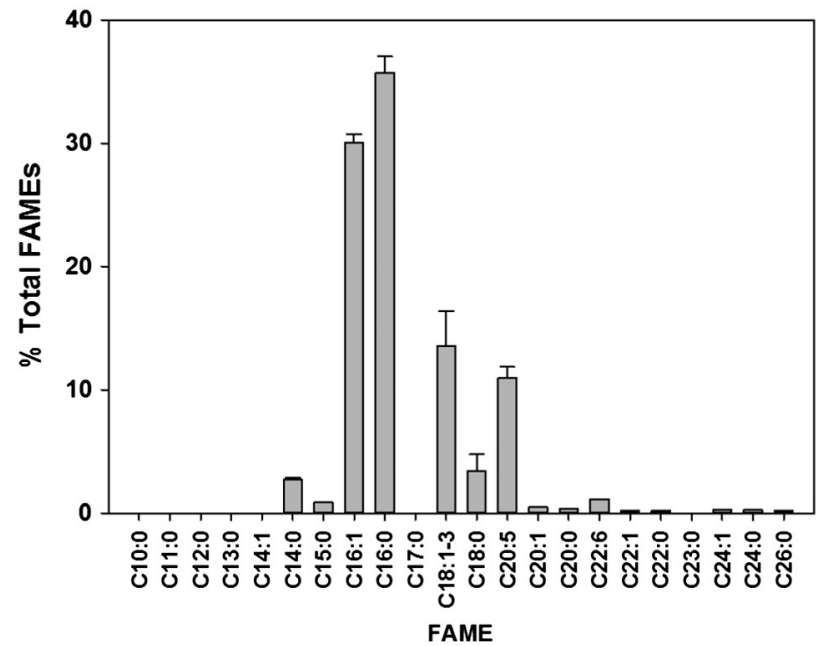

Fig. 9. FAME speciation as $\%$ total FAME in $2 \mathrm{mM}$ Si cultures $(\mathrm{n}=3)$. 
[60] and Vaulot et al. [61] revealed that for the diatom, Thalassiosira weisflogii and the coccolithophore, Hymenomonas carterae, $\mathrm{NO}_{3}^{-}$and $\mathrm{Si}$ limitation resulted in halting the cell cycle at G1 and late G1 \& G2, respectively. It is possible that the two combined nutrient limitations at different periods within the cell cycle may contribute to cellular stress, ultimately leading to enhanced lipid accumulation. These results indicate that the combination of $\mathrm{Si}$ and $\mathrm{NO}_{3}^{-}$limitation has the potential to increase TAG accumulation in lipid producing diatoms.

In this study, Nile Red fluorescence increased once the $\mathrm{pH}$ had increased to above $\mathrm{pH} 9$, prior to nutrient depletion as shown in Figs. 4A and $5 \mathrm{~F}$, which is similar to the observations reported in Gardner et al. $[9,10,15]$. Cultures exposed to coincident $\mathrm{Si}$ and $\mathrm{NO}_{3}^{-}$limitations, as well as $\mathrm{HCO}_{3}^{-}$, exhibited the highest Nile Red fluorescence intensities of all the conditions tested.

Previous studies have discussed the role of a carbon concentrating mechanism (CCM), involving carbonic anhydrase (CA) and bicarbonate transporter activity [62-65]. After switching from high (5\%) to low $\mathrm{CO}_{2}$ (atmospheric concentration) conditions, it is thought that CA and bicarbonate transporter activity increase, resulting in elevated inorganic carbon transport into the cell, and chloroplast in close proximity of RuBisCO and may potentially be stored as lipids [10]. Here RGd- 1 cultures were not supplemented with $\mathrm{CO}_{2}$, such that by late exponential phase of growth, cultures were likely carbon limited, with increased carbonic anhydrase activity similar to the mechanism discussed by Gardner et al. [10]. Once the cultures were supplemented with $\mathrm{HCO}_{3}^{-}$, carbonic anhydrases shuttled more inorganic carbon across both the cell and chloroplast membranes resulting in higher $\mathrm{CO}_{2}$ concentrations near RuBisCO, leading to increased lipid accumulation. This idea is corroborated by an increase in $\alpha$-carbonic anhydrase gene expression during stationary phase following $\mathrm{NO}_{3}^{-}$and $\mathrm{PO}_{4}^{3-}$ depletion in P. tricornutum [59]. It is possible that the combination of cell cycle arrest at both G1 and G2 of the cell cycle, combined with enhanced CCM activity due to sodium bicarbonate addition leads to substantially higher lipid accumulation, as measured by Nile Red fluorescence.

\subsection{Comparison of Nile Red and TAG}

Lipid analysis by gas chromatography indicated that when Si was present, RGd-1 accumulated a minimum of 32\% (w/w) TAG and $70 \%(\mathrm{w} / \mathrm{w}$ ) biodiesel potential (FAME) normalized to AFDW. The BP (in $g$ FAME per $g$ of biomass) was found to be more than twice the percent TAG which is indicative of transesterification of other lipids (e.g. phospholipids) that contribute to biofuel potential as described by Wahlen et al. [66]. The results in Fig. 7 and Table 1 are promising (70-80\% BP), even though some frustule breakage may have occurred during centrifugation as a part of the harvesting process. During the late stationary phase of growth, microscopic observations showed frustule breakage, with lipid vacuoles exiting the cells (data not shown). This phenomenon may potentially be beneficial for lipid extraction on a large scale, but might have resulted in an underestimation of the lipid productivity of RGd-1 cultures. A current obstacle in the algal biofuels industry lies in energy efficient and safe protocols to extract lipid from cells. Therefore, it is possible that choosing strains that rupture easily when full of lipid, may be advantageous for harvesting and lipid extraction. In fact, the advantage of easily breakable cell walls may increase the viability of diatoms for biofuel production, though overly fragile diatoms may lead to lipid loss and culture contamination by heterotrophs.

\section{Conclusions}

RGd-1 is a novel diatom with the ability to accumulate high concentrations of lipids, and has not been described previously. By increasing the Si concentration, we were able to effectively increase the cell concentration, but growth rates are still lower than desired. Once Si was depleted from the growth medium, lipid accumulation was promoted.
Further, the results of this study indicate that multiple combined stresses can enhance lipid accumulation, leading to higher lipid content and biofuel potential. Specifically, $\mathrm{Si}$ and $\mathrm{NO}_{3}^{-}$depletion, combined with $\mathrm{HCO}_{3}^{-}$ addition, and potentially $\mathrm{pH}$ stress contributed to this increase. The ability of diatom cell walls to break easily when cells are full of lipid during the late stationary phase of growth may provide an advantage over green algae in regards to lipid extraction for use in biodiesel production. Further investigation is underway to determine optimal growth conditions for use in large-scale growth systems.

Supplementary data to this article can be found online at http://dx. doi.org/10.1016/j.algal.2014.04.002.

\section{Acknowledgments}

The authors would like to thank all members of the MSU Algal Biofuels Group. Additionally, the authors especially thank John Barnick and Ellen Lauchnor for their help with running the ICP-MS, Ann Willis at the CBE for assistance in running IC, as well as Hannah Newhouse and Dan McDonald for assisting with clone libraries and Nate Murphy for experimental support. The authors acknowledge Yellowstone National Park as well as funding for the establishment and operation of the Environmental and Biofilm Mass Spectrometry Facility at Montana State University (MSU) through the Defense University Research Instrumentation Program (DURIP, Contract Number: W911NF0510255) and the MSU Thermal Biology Institute from the NASA Exobiology Program (Project NAG5-8807). Funding Sources: U.S. Department of Energy: Office of Biomass Programs grant DE-FG36-08G018161, Office of Energy Efficiency and Renewable Energy (EERE) Biomass Program under Contract No. DE-EE0003136 and National Science Foundation CHE1230632. This work was additionally made possible by Betsy Pitts and the microscopy facilities at the Center for Biofilm Engineering, which was supported by funding obtained from the NSF-MRI Program and the M.J. Murdock Charitable Trust.

\section{References}

[1] Y. Chisti, Biodiesel from microalgae, Biotechnol. Adv. 25 (2007) 294-306.

[2] P. Schenk, S. Thomas-Hall, E. Stephens, U. Marx, J. Mussgnug, C. Posten, O. Kruse, B. Hankamer, Second generation biofuels: high-efficiency microalgae for biodiesel production, BioEnergy Res. 1 (2008) 20-43.

[3] P.T. Pienkos, A. Darzins, The promise and challenges of microalgal-derived biofuels, Biofuels Bioprod. Biorefin. 3 (2009) 431-440.

[4] F. Sissine, Energy Independence and Security Act of 2007: a Summary of Major Provisions, DTIC Document, 2007.

[5] R. Davis, A. Aden, P.T. Pienkos, Techno-economic analysis of autotrophic microalgae for fuel production, Appl. Energy 88 (2011) 3524-3531.

[6] A.L. Ahmad, N.H.M. Yasin, C.J.C. Derek, J.K. Lim, Microalgae as a sustainable energy source for biodiesel production: a review, Renew. Sust. Energ. Rev. 15 (2011) 584-593.

[7] T.M. Mata, A.n.A. Martins, N.S. Caetano, Microalgae for biodiesel production and other applications: a review, Renew. Sust. Energ. Rev. 14 (2010) 217-232.

[8] M. Griffiths, S. Harrison, Lipid productivity as a key characteristic for choosing algal species for biodiesel production, J. Appl. Phycol. 21 (2009) 493-507.

[9] R. Gardner, P. Peters, B. Peyton, K. Cooksey, Medium pH and nitrate concentration effects on accumulation of triacylglycerol in two members of the Chlorophyta, J. Appl. Phycol. 23 (2011) 1005-1016.

[10] R. Gardner, K. Cooksey, F. Mus, R. Macur, K. Moll, E. Eustance, R. Carlson, R. Gerlach, M. Fields, B. Peyton, Use of sodium bicarbonate to stimulate triacylglycerol accumulation in the chlorophyte Scenedesmus sp. and the diatom Phaeodactylum tricornutum, J. Appl. Phycol. (2012) 1-10.

[11] Q. Hu, M. Sommerfeld, E. Jarvis, M. Ghirardi, M. Posewitz, M. Seibert, A. Darzins, Microalgal triacylglycerols as feedstocks for biofuel production: perspectives and advances, Plant J. 54 (2008) 621-639.

[12] Q. Hu, Environmental effects on cell composition, in: A. Richmond (Ed.), Handbook of Microalgal Culture, Blackwell, Oxford, 2004, pp. 83-93.

[13] J.B. Guckert, K.E. Cooksey, Triglyceride accumulation and fatty acid profile changes in Chlorella (Chlorophyta) during high pH-Induced cell cycle inhibition, J. Phycol. 26 (1990) 72-79.

[14] P.G. Roessler, Effects if silicon deficiency in lipid composition and metabolism in the diatom Cyclotella cryptica, J. Phycol. 24 (1988) 394-400.

[15] R.D. Gardner, E. Lohman, R. Gerlach, K.E. Cooksey, B.M. Peyton, Comparison of $\mathrm{CO}_{2}$ and bicarbonate as inorganic carbon sources for triacylglycerol and starch accumulation in Chlamydomonas reinhardtii, Biotechnol. Bioeng. 110 (2013) 87-96.

[16] D. White, A. Pagarette, P. Rooks, S. Ali, The effect of sodium bicarbonate supplementation on growth and biochemical composition of marine microalgae cultures, J. Appl. Phycol. 25 (2013) 153-165. 
[17] H.W. Bischoff, H.C. Bold, Some Soil Algae from Enchanted Rock and Related Algal Species, 1963. Austin : [s.n.]).

[18] L. Provasoli, J.J.A. McLaughlin, M.R. Droop, The development of artificial media for marine algae, Arch. Microbiol. 25 (1957) 392-428.

[19] F.E. Round, D.G. Mann, R.M. Crawford, The Diatoms: Biology \& Morphology of the Genera, Cambridge University Press, Cambridge, 1990.

[20] P. Bhargava, K.M. Medicherla, From isolation of potential microalgal strains to strain engineering for biofuel, The Science of Algal Fuels, Springer, 2012. 63-81.

[21] S. Radha, A.A. Fathima, S. Iyappan, M. Ramya, Direct colony PCR for rapid identification of varied microalgae from freshwater environment, J. Appl. Phycol. (2013) 1-5

[22] M. Majaneva, J.M. Rintala, M. Piisilä, D. Fewer, J. Blomster, Comparison of wintertime eukaryotic community from sea ice and open water in the Baltic Sea, based on sequencing of the 18S rRNA gene, Polar Biol. 35 (2012) 875-889.

[23] S.Y. Moon-van der Staay, R. De Wachter, D. Vaulot, Oceanic 18S rDNA sequences from picoplankton reveal unsuspected eukaryotic diversity, Nature 409 (2001) 607-610.

[24] T.J. White, T. Bruns, S. Lee, J. Taylor, Amplification and direct sequencing of fungal ribosomal RNA genes for phylogenetics, in: M.A. Innis, D.H. Gelfand, J.J. Sninksky, T.J. White (Eds.), PCR Protocols: A Guide to Methods and Applications, Academic Press, Inc., San Diego, 1990, pp. 315-322.

[25] M. Gardes, T.J. White, J.A. Fortin, T.D. Bruns, J.W. Taylor, Identification of indigenous and introduced symbiotic fungi in ectomycorrhizae by amplification of nuclear and mitochondrial ribosomal DNA, Can. J. Bot. 69 (1991) 180-190.

[26] A.W. Coleman, A. Suarez, L.J. Goff, Molecular delineation of species and syngens in Volvocacean green algae (Chlorophyta), J. Phycol. 30 (1994) 80-90.

[27] T.G. Mitchell, E.Z. Freedman, T.J. White, J.W. Taylor, Unique oligonucleotide primers in PCR for identification of Cryptococcus neoformans, J. Clin. Microbiol. 32 (1994) 253-255.

[28] B. Wawrik, J.H. Paul, F.R. Tabita, Real-time PCR quantification of rbcL (ribulose-1,5bisphosphate carboxylase/oxygenase) mRNA in diatoms and pelagophytes, Appl. Environ. Microbiol. 68 (2002) 3771-3779.

[29] A.M. Waterhouse, J.B. Procter, D.M.A. Martin, M. Clamp, G.J. Barton, Jalview version 2-a multiple sequence alignment editor and analysis workbench, Bioinformatics 25 (2009) 1189-1191.

[30] R.E. Andersen, Algal Culturing Techniques, Academic Press, San Francisco, 2005.

[31] R.K. Iler, The Colloid Chemistry of Silica and Silicates, Cornell University Press, Ithaca, NY, 1955.

[32] R.K. Iler, The Chemistry of Silica: Solubility, Polymerization, Colloid and Surface Properties, and Biochemistry, Wiley-Interscience, 1979.

[33] C. Zhu, Y. Lee, Determination of biomass dry weight of marine microalgae, J. Appl Phycol. 9 (1997) 189-194.

[34] P. Chelf, Environmental control of lipid and biomass production in two diatom species, J. Appl. Phycol. 2 (1990) 121-129.

[35] R. Ritchie, Universal chlorophyll equations for estimating chlorophylls a, b, c, and and total chlorophylls in natural assemblages of photosynthetic organisms using acetone, methanol, or ethanol solvents, Photosynthetica 46 (2008) 115-126.

[36] K.E. Cooksey, J.B. Guckert, S.A. Williams, P.R. Callis, Fluorometric determination of the neutral lipid content of microalgal cells using Nile Red, J. Microbiol. Methods 6 (1987) 333-345

[37] D. Elsey, D. Jameson, B. Raleigh, M.J. Cooney, Fluorescent measurement of microalga neutral lipids, J. Microbiol. Methods 68 (2007) 639-642.

[38] W. Chen, C. Zhang, L. Song, M. Sommerfeld, Q. Hu, A high throughput Nile Red method for quantitative measurement of neutral lipids in microalgae, J. Microbiol. Methods 77 (2009) 41-47.

[39] G.B. Casella, R.L. Berger, Statistical Inference, Duxbery Press, Belmont, California, 1990.

[40] M. Griffiths, R. van Hille, S. Harrison, Selection of direct transesterification as the preferred method for assay of fatty acid content of microalgae, Lipids 45 (2010) 1053-1060.

[41] N. Bigelow, W. Hardin, J. Barker, S. Ryken, A. MacRae, R. Cattolico, A comprehensive GC-MS sub-microscale assay for fatty acids and its applications, J. Am. Oil Chem. Soc. 88 (2011) 1329-1338.

[42] S.R. Smith, R.M. Abbriano, M. Hildebrand, Comparative analysis of diatom genomes reveals substantial differences in the organization of carbon partitioning pathways, Algal Res. 1 (2012) 2-16.
[43] E. Eustance, R. Gardner, K. Moll, J. Menicucci, R. Gerlach, B. Peyton, Growth, nitrogen utilization and biodiesel potential for two Chlorophytes grown on ammonium, nitrate or urea, J. Appl. Phycol. 25 (2013) 1663-1667.

[44] S. Taguchi, J.A. Hirata, E.A. Laws, Silicate deficiency and lipid synthesis of marine diatoms, J. Phycol. 23 (1987) 260-267.

[45] C. Jeffryes, J. Rosenberger, G.L. Rorrer, Fed-batch cultivation and bioprocess modeling of Cyclotella sp. for enhanced fatty acid production by controlled silicon limitation, Algal Res. 2 (2013) 16-27.

[46] T.Y. Eizadora, F.J. Zendejas, P.D. Lane, S. Gaucher, B.A. Simmons, T.W. Lane, Triacylglycerol accumulation and profiling in the model diatoms Thalassiosira pseudonana and Phaeodactylum tricornutum (Bacilariophyceae) during starvation, J. Appl. Phycol. 21 (2009) 669-681.

[47] O. Pulz, W. Gross, Valuable products from biotechnology of microalgae, Appl. Microbiol. Biotechnol. 65 (2004) 635-648.

[48] L Rodolfi, G. Chini Zittelli, N. Bassi, G. Padovani, N. Biondi, G. Bonini, M.R. Tredici, Microalgae for oil: strain selection, induction of lipid synthesis and outdoor mass cultivation in a low-cost photobioreactor, Biotechnol. Bioeng. 102 (2009) 100-112.

[49] A. Fuggi, V. Di Martino Rigano, V. Vona, C. Rigano, Nitrate and ammonium assimilation in algal cell-suspensions and related $\mathrm{pH}$ variations in the external medium, monitored by electrodes, Plant Sci. Lett. 23 (1981) 129-138.

[50] M. Hildebrand, A.K. Davis, S.R. Smith, J.C. Traller, R. Abbriano, The place of diatoms in the biofuels industry, Biofuels 3 (2012) 221-240.

[51] J.A. Berges, D.O. Charlebois, D.C. Mauzerall, P.G. Falkowski, Differential effects of nitrogen limitation on photosynthetic efficiency of photosystems I and II in microalgae, Plant Physiol. 110 (1996) 689-696.

[52] G.E. Fogg, Photosynthesis and formation of fats in a diatom, Ann. Bot. 20 (1956) 265-285.

[53] A. Ben-Amotz, T.G. Tornabene, W.H. Thomas, Chemical profile of selected species of microalgae with emphasis on lipids, J. Phycol. 21 (1985) 72-81.

[54] M. Piorreck, K.H. Baasch, P. Pohl, Biomass production, total protein, chlorophylls, lipids and fatty acids of freshwater green and blue-green algae under different nitrogen regimes, Phytochemistry 23 (1984) 207-216.

[55] N.S. Shifrin, S.W. Chisholm, Phytoplankton lipids: interspecific differences and effects of nitrate, silicate and light-dark cycles, J. Phycol. 17 (1981) 374-384.

[56] H.A. Spoehr, H.W. Milner, The chemical composition of Chlorella; effect of environmental conditions, Plant Physiol. 24 (1949) 120-149.

[57] Y. Suen, J.S. Hubbard, G. Holzer, T.G. Tornabene, Total lipid production of the green alga Nannochloropsis sp. under different nitrogen regimes, J. Phycol. 23 (1987) 289-296.

[58] E.H. Burrows, N.B. Bennette, D. Carrieri, J.L. Dixon, A. Brinker, M. Frada, S.N. Baldassano, P.G. Falkowski, G.C. Dismukes, Dynamics of lipid biosynthesis and redistribution in the marine diatom Phaeodactylum tricornutum under nitrate deprivation, BioEnergy Res. 5 (2012) 876-885.

[59] J. Valenzuela, A. Mazurie, R.P. Carlson, R. Gerlach, K.E. Cooksey, B.M. Peyton, M.W. Fields, Potential role of multiple carbon fixation pathways during lipid accumulation in Phaeodactylum tricornutum, Biotechnol. Biofuels 5 (2012) 1-17.

[60] R.J. Olson, D. Vaulot, S.W. Chisholm, Effects of environmental stresses on the cell cycle of two marine phytoplankton species, Plant Physiol. 80 (1986) 918-925.

[61] D. Vaulot, R. Olson, S. Merkel, S. Chisholm, Cell-cycle response to nutrient starvation in two phytoplankton species, Thalassiosira weissflogii and Hymenomonas carterae, Mar. Biol. 95 (1987) 625-630.

[62] G.G. Bozzo, B. Colman, Y. Matsuda, Active transport of $\mathrm{CO}_{2}$ and bicarbonate is induced in response to external $\mathrm{CO}_{2}$ concentration in the green alga Chlorella kessleri, J. Exp. Bot. 51 (2000) 1341-1348.

[63] J.R. Reinfelder, Carbon concentrating mechanisms in eukaryotic marine phytoplankton, Annu. Rev. Mar. Sci. 3 (2011) 291-315.

[64] J. Raven, Inorganic carbon acquisition by eukaryotic algae: four current questions, Photosynth. Res. 106 (2010) 123-134.

[65] J.A. Raven, M. Giordano, J. Beardall, S.C. Maberly, Algal evolution in relation to atmospheric $\mathrm{CO}_{2}$ : carboxylases, carbon-concentrating mechanisms and carbon oxidation cycles, Philos. Trans. R. Soc. B Biol. Sci. 367 (2012) 493-507.

[66] B.D. Wahlen, R.M. Willis, L.C. Seefeldt, Biodiesel production by simultaneous extraction and conversion of total lipids from microalgae, cyanobacteria, and wild mixedcultures, Bioresour. Technol. 102 (2011) 2724-2730. 